\title{
The Organic Integration and Innovative Development of Financial Accounting and Management Accounting
}

\author{
Xuemin Bai \\ Shandong Huayu University of Technology, School of Economics and Management 253034
}

Keywords: Financial Accounting; Management Accounting; Integration Innovative

\begin{abstract}
With the rapid development of socialist market economy, our country has put forward higher requirements for the integration of financial accounting and management accounting. This paper first introduces the definition of financial accounting and management accounting, then analyzes the premise of the integration of financial accounting and management accounting, and finally discusses the current situation of the integration of financial accounting and management accounting, hoping to effectively improve the integration level of financial accounting and management accounting and create conditions for the rapid and healthy development of accounting in China.
\end{abstract}

\section{Introduction}

As a comprehensive system of information production and utilization, accounting can often be divided into two modules: management accounting and financial accounting. In the traditional enterprise financial activities, the two often work independently, but with the continuous development of the times, the close relationship between financial accounting and management accounting is increasing, so the integration of financial accounting and management accounting has gradually become an important way to improve the level of financial management at this stage. In order to further explore the integration strategy of financial accounting and management accounting, the definition and connotation of financial accounting and management accounting are briefly discussed as follows.

\section{Definition of Financial Accounting and Management Accounting}

\subsection{Definition of financial accounting}

Financial accounting is one of the necessary posts in an enterprise. Its main task is to complete systematic and comprehensive fund management by means of accounting and supervision within a certain capital cycle. According to the process of accounting and supervision, its main objects of supply include enterprise investors, creditors and other entities. Through financial accounting, it can understand and master the relevant financial information of the enterprise, thus guiding the next investment activities.

\subsection{Definition of management accounting}

The purpose of management accounting is to analyze and sort out the process of financial activities, summarize and feedback the financial statements sorted out by financial accounting, and then give corresponding suggestions and optimization strategies to decision makers. Therefore, management accounting is more inclined to decision-making suggestions and management than financial accounting, which is an important condition for improving the quality of internal financial management and guiding the steady and rapid development of enterprises. From a functional point of view, management accounting can also be called internal accounting.

\section{The Premise of the Integration of Financial Accounting and Management Accounting}

The integration of financial accounting and management accounting is a necessary condition to meet the current situation of enterprise financial management and improve the scientific and stable 
management of enterprises. The value of the integration mainly comes from the common ground of their comprehensive action mechanism and connotation extension.

\subsection{Comprehensive action mechanism}

Objectively speaking, the main task of accounting work is to sort out financial information and guide enterprises' decisions, including investment decisions, management decisions and other types of decisions. That is to say, the basic goal of accounting is to guide the development of enterprises, and this kind of decision-making work must rely on information feedback and decision-making suggestions of management accounting if it is to reflect its value. However, management accounting alone cannot complete the control and analysis of basic financial information. Therefore, financial accounting should operate as the basic premise of management accounting. After financial accounting completes the collection and collation of information, management accounting can make corresponding decision-making suggestions based on the collated information, thus affecting the decision-making and development of enterprises. From the perspective of action mechanism, the two are closely related and have the characteristics of common action. Only by mutual fusion and infiltration can they show their proper fusion value.

\subsection{The common point of connotation and extension}

Management activities and information systems themselves have certain common ground. In management activities, there are certain differences in views and perspectives on issues, which are only differences in perspectives and tend to be consistent in nature of work. Whether it is financial accounting or management accounting, the work done is based on the current financial situation and economic situation of the enterprise. At the same time, regardless of the angle, both will also participate in the decision-making and business activities of the enterprise and have a certain influence on the management decision-makers of the enterprise. However, this influence is only different from more and less, and there is no essential difference, which is also the basic condition for the integration of the two.

\section{Current Situation of Financial Accounting and Management Accounting Integration in China}

According to the current situation of the integration of financial accounting and management accounting in China, there are still obvious features of working independently and isolated from each other. From the perspective of overall development, the lack of integration of financial accounting and management accounting is mainly limited and restricted by the following two factors.

\subsection{Insufficient attention to management accounting}

As a business manager, the lack of attention to management accounting can be said to be the main reason for the slow integration of financial accounting and management accounting. This is due to the fact that most small and medium-sized enterprises have fewer financial management personnel, and it is already very difficult to achieve professional financial management, and it is even more difficult for people to carry out related activities of management accounting. Most decision-making managers of small and medium-sized enterprises have misunderstandings about financial management, believing that financial management is " managing accounts" and completing the task by performing simple financial calculations to obtain financial statements. They do not have a high level of understanding of the work of management accounting, do not understand it deeply and do not attach importance to it, resulting in little involvement in the feedback of financial information and the auxiliary functions of decision - making. As a result, financial management personnel are forced to work only in financial accounting, which almost does not involve management accounting, so there is no integration and development of financial accounting and management accounting. 


\subsection{Lack of scientific and reasonable integration methods}

At present, some domestic enterprises are gradually aware of the necessity of the integration of financial accounting and management accounting, but they are struggling to find a scientific and reasonable integration method, so the integration of financial accounting and management accounting is in the stage of trial development and the overall effect is not ideal. In fact, accounting activity is a very complicated activity, which involves not only the management of funds and accounts, but also the allocation of internal resources and the guidance of decision-making in the sustainable development of enterprises. Therefore, it has high requirements for the comprehensive quality and decision-making ability of financial managers and decision makers of enterprises. Under such conditions, if we want to seek a scientific integration method, we must prepare for the integration of financial accounting and management accounting to avoid greater resistance to integration in enterprise decision - making. However, from the perspective of the integration of financial accounting and management accounting in most domestic enterprises, it is obvious that preparations for this aspect have not been made, which is also an important reason for the poor integration of financial accounting and management accounting.

\section{Innovation Strategy of Financial Accounting and Management Accounting Integration in China}

\subsection{Coordination of business departments}

The integration of financial accounting and management accounting cannot be separated from the attention of leaders. Through the leadership's attention, the interpersonal relationship and post responsibilities in accounting activities can be clearly guided. By learning accounting knowledge, managers can also better adjust the relationship between financial accounting and management accounting, give full play to their respective advantages and values, and achieve further integration. From the perspective of department cooperation, the past mode of independent work has developed into a win-win mode of integration, which requires department heads to deal with their responsibilities first, simplify complex interpersonal relationships as much as possible, ensure the stability of the working environment within the organization, and then conduct detailed analysis and discussion on work matters. In this process, the head of the department should play an active role in taking the lead, and effectively improve the coordination and stability within the organization by coordinating the relationship between members and business contacts and between leaders and members. In the process of establishing and perfecting the new integration development system, we need to rely on our own authority to resist some resistance factors and ensure the effectiveness of the integration of the organization, which is a necessary condition for the successful integration of financial accounting and management accounting.

\subsection{To realize the refinement of work}

The integration of financial accounting and management accounting must be precise, otherwise it will lose its value. In order to realize the refinement of work, it is first necessary to make preparations for the integration of financial accounting and management accounting and provide a list of original accounting information. Secondly, combined with the list of the original accounting information catalog, the classification and coding process is carried out, and the corresponding database and information sharing platform are established to carry out the integration management of financial accounting and management accounting on the platform. Finally, combined with the current situation of the original accounting subjects, add some merged accounting vouchers to realize the effective merger of information sources. You can add statistical information codes according to the actual needs, or you can merge them by setting up information columns to record and count non-monetary information, and reflect these contents in the account books to provide the necessary guarantee for enterprises to successfully complete their business decision - making. 


\subsection{To improve the comprehensive quality of personnel and cultivate compound talents}

As the main body of the integration of financial accounting and management accounting, the professional quality and background of financial personnel are also crucial to improve the integration effect. In the process of enterprise development, if more attention can be paid to financial management, the training of compound talents will be completed through active on-the-job training and raising the recruitment threshold. For example, recruiting personnel with dual degrees and integration management experience can effectively reduce the difficulty of integration of financial accounting and management accounting and better complete the integration of financial accounting and management accounting. In addition, the decision makers of the enterprise should communicate with the financial management department more, understand the current financial management situation and the problems existing in the financial information, and listen to the opinions and suggestions of the financial management personnel more, so as to enhance the management ability of the financial personnel by means of backward development, give full play to the integration effect of financial accounting and management accounting, complete the technical reform and integration development innovation of financial management as soon as possible, and create conditions for realizing the innovative operation of the enterprise.

\section{Summary}

To sum up, the integration of financial accounting and management accounting can not be separated from the close cooperation between departments. Through refinement of work and innovation of format, the integration process of the two can be effectively promoted, thus creating conditions for better completion of financial management. In addition, as the main body of financial management activities, the cultivation of talents is still a necessary condition for the integration of financial management, financial accounting and management accounting in enterprises. Only by improving the comprehensive quality of personnel and cultivating compound talents more suitable for the development needs of enterprises can the task of integration and innovation be better completed and a solid foundation be laid for the smooth completion of financial management in enterprises in China.

\section{References}

[1] Meng Jing. Analysis on the Transformation from Financial Accounting to Management Accounting under the New Situation[J/OL]. China Business \& Trade, 2018(35): 133-134 [2018-12-21].

[2] Dong Lilan. Discussion on the Integration of Enterprise Financial Accounting and Management Accounting[J/OL]. China Business \& Trade, 2018(35):141-142[2018-12-21].

[3] Bai Shuang. Integration of Financial Accounting and Management Accounting in the Age of Artificial Intelligence[J/OL]. Journal of Henan Education Institute (Philosophy and Social Science Edition),2018(06) [2018-12-21].

[4] Li Jiarui. Analysis and Research on the Transformation from Financial Accounting to Management Accounting under the Background of Big Data[J/OL]. China Business \& Trade, $1-2[2018-12-21]$.

[5] Zhu Min. Discussion On the Integration of Financial Accounting and Management Accounting[J]. Marketing Management Review, 2018(12):239-240. 